\title{
A HYBRID MODEL OF COMPETITIVE ADVANTAGE BASED ON BOURDIEU CAPITAL THEORY AND COMPETITIVE INTELLIGENCE USING FUZZY DELPHI AND ISM-GRAY DEMATEL (STUDY OF IRANIAN FOOD INDUSTRY)
}

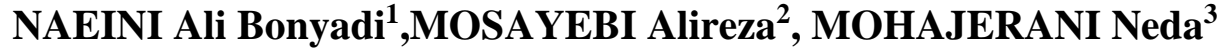 \\ 1 Iran University of Science and Technology, Tehran (IRAN) \\ 2 Iran University of Science and Technology, Tehran (IRAN) \\ 3 Alzahra University Tehran (IRAN) \\ E-mails: alireza.mosayebi88@gmail.com
}

\begin{abstract}
Competitive advantage is an important issue emphasized in management and strategic planning over the past few years. This study was aimed to comprehensively evaluate competitive advantage and design and explain a hybrid model of competitive advantage based on Bourdieu capital theory and competitive intelligence using fuzzy Delphi and ISM-Gray DEMATEL in Iran Food Industry.

This article applies a method to managers, with the findings indicating that the firms will not be able to achieve competitive advantage in the market unless they are formed by a high start-up capital and a high competitive intelligence and awareness on the part of the managers as to the business conditions. Such factors enable organizations to make better use of their own cultural and social capitals. Also, the optimal use of social and cultural capitals ameliorates the competitive advantages of the organizations. The authenticity and the economic values added of organizations are further enhanced by obtaining competitive advantage. Promoting organizations' credit and brand improves their economic and market value added, which, in turn augment their capitals and economic assets.
\end{abstract}

Keywords: competitive advantage, economic capital, social capital, symbolic capital, cultural capital, competitive intelligence

JEL:L10

UDC: 005.332.4:338.439(55)

COBISS.SR-ID 277949708 


\section{INTRODUCTION}

As far as food industry is concerned, there exists a major need for planning in many countries due to the following reasons (Antelo, Magdalena, \& Reboredo, 2017; Chavas, 2017; Perez, Ribera, \& Palma, 2017; Nestle, 2013; Vasconcellos, 2003; Kress-Rogers \& Brimelow, 2001; Traill \& Pitts, 1998; Menrad, 2004):

- Major parts of its value reside in the native country, hence providing a suitable employment condition.

- It provides more profits and values added in every stage of supply chain

- Regarding the locality of the chain of raw material to consumption (value chain), food industry and agriculture are less sensitive to and can survive in the face of external risks.

- High effect of new technologies in increasing the speed and quality as well as reducing the production costs.

- Food industry notably impacts the lifestyle and culture of various social classes.

The increased net value of agricultural products improves indigenous investment in this sector. Moreover, as a result of the availability of food and conversion industries, the brokerage of agricultural products diminishes, thereby leading to a more healthy economy. Supplying food and providing food security are of great importance, a direction in which conversion industry plays a critical role. Owing to the high competition in this field, many manufacturing companies try to achieve competitive advantage, hence higher market share, profitability, authenticity and so forth ()Harris \& Ogbonna, 2001; Klimek \& Hansen, 2017; Massa \& Testa, 2009; Topliceanu, Bibire, \& Nistor, 2015).

In so far as Iran economy is concerned, food and agriculture occupy prominent positions. The agriculture sector plays a major part in economy because of the availability of potential facilities, arable areas, climate variation, high population and employment in rural parts, presence of economic superiority such as relative superiority of investment in this field and the value of manufacturing assets and capital. Currently, Iran economy is in dire need for the development of products that promote domestic economy and improve non-petroleum exports because. In this regard, conversion industries have a high importance because they play critical roles in domestic economy and, simultaneously, affect non-petroleum export (Valentine; John \& Rice, 2013; Tehran Times, 2012). According to Porter's competitive advantage model, the higher the attraction of an industry the more the investment and the competition within that industry becomes. In such contest, the firm with the higher competitive advantage can prevail (Davcik \& Sharma, 2016; Hsu, 2013; Perren, 2013; Rui, Zhang, \& Shipman, 2017; Wongprawmas \& Canavari, 2017).

Broadly speaking, environmental and organizational factors affect competitive advantage. The former refers to achieving competencies through external opportunities, whereas the latter considers the competitive advantage in the context of resource-based view (RNV), competencebased competition (CBC) and dynamic capabilities view (DCV). The main focus of the present study is DCV which refers to the renovation of structures according to environmental conditions. DCV deals with relational and network capabilities, trust, cooperation and interorganizational alliance ()Borseková, Vaňová, \& Vitálišová, 2016; Jensen, Cobbs, \& Turner, 2016; Peters, Wieder, Sutton, \& Wakefield, 2016; Teixeira \& Werther, 2013().

Competitive intelligence in DCV includes identifying the nature of change, predicting future market trends, competition, technology, innovation, and customers' preferences and behavioral patterns. The main areas covered by DCV are competitor-related intelligence, 
technology intelligence, strategic intelligence and social intelligence. Market intelligence monitors the current and future demands of customers and their tendency to new markets, segmentation opportunities, major changes in market and competitors distribution. Competitor intelligence evaluates the evolution of competitors' competitive strategies via systematic monitoring of competitors' structure, new alternative products and the newcomers of industry. Technology intelligence refers to the profits of current and new technologies and predicts the technologies which will be outcompeted and those that will prevail. Strategic intelligence includes financial and tax rules, political, and human resource and social issues. These four types of intelligence, all interrelated, consider and analyze the socio-behavioral trends ((Ali Köseoglu, Ross, \& Okumus, 2016; Mariadoss, Milewicz, Lee, \& Sahaym, 2014; Sewdass \& Toit, 2014; Shih, Liu, \& Hsu, 2010).

Competitive advantage may bring economic value added (EVA) and market value added (MVA). EVA, also called economic profit, is an indicator for the evaluation of financial performance according to surplus wealth calculated by the deduction of capital cost from the operational profit (after deduction of tax), (Borseková et al., 2016; Davcik \& Sharma, 2016; Peters et al., 2016 Lieberman, Garcia-Castro \& Balasubramanian, 2017).

Bourdieu (1984), a sociologist, developed a comprehensive theory about the social and organizational capital and advantage creation which can be considered as the essence of many theories and visions of advantage. According to Bourdieu, humans do not live in a vacuum but in a number of fields that are composed of elements including economic, cultural, social and symbolic capitals. He who accords with such elements is able to achieve advantage.

1- Economic capital: The word capital first came to mean "physical" until 1960s. Physical capital usually refers to building and machinery (Shi, Connelly \& Hoskisson, 2017)

2- Social capital, Bourdieu argues, represents a collection of relationships, contacts, familiarities, friendships and debts (symbolic debts) that form networks.

3- Symbolic capital is a set of related customs to honor or gratitude rules, belonging to a person or a group. Such capital stems from one's charisma, experience, religion, race, prestige, dignity, respect and individual capabilities. Symbolic capital is a part of cultural capital that means legitimating, defining and evaluating. According to Bourdieu, symbolic capital can be considered as a separate capital and as the upper bound of other capital types.

4-Cultural capital, Bourdieu holds, refers to information on cultural beliefs and customs and is a behavioral criteria, promoting success and achievement. Cultural capital refers to the ability to perceive and apply cultural goods that appease sustainable tendencies accumulated through socialization. Bourdieu maintained that the theory, on top of macro-level impacts, can lead to variation and competitive advantage in micro communities such various industries and organizations ((Barthélemy, 2017 ; Baxter \& Chua, 2008; Cooper \& Coulson, 2014; Ihlen, 2005, 2007; Kitchin \& David Howe, 2013; Sieweke, 2014).

Reviewing various studies, especially those conducted in the field of food industry, it was revealed that, despite the importance of this sector, there have been few studies proposing a compendious and practical model for achieving competitive advantage. The main objective of the present, therefore, was to find out how the indices proposed by Bourdieu can create competitive advantage in food industry, how competitive intelligence can bring about competitive advantage in food industry and other factors affecting competitive advantage. 


\section{METHODOLOGY}

This is an applied study conducted as a descriptive survey in which a combination of library and field methods were implemented. Library method was used to identify research variables, indices and dimensions of economic, cultural, social an intellectual capitals and competitive intelligence. A survey was carried out to collect the required data. Statistical population includes all corporations working within Iran food industry. Sampling was performed by nonrandomized judgment method where eight firms were proposed by national standard organization, health and medical ministry and food and drug organization. The first three firms, chosen based on market share over the past five years (playing major roles in the export of nonpetroleum products), were interviewed to identify the native and food-specific indices. The size of the sample did not matter in this study, rather the importance was allocated to experts in group decision making.

The experts had to meet the following criteria:

- Education in the fields related to strategic management

- MA degree

- A minimum of ten-year experience in marketing or strategic planning and management

- Work experience as manager or assistant for at least for 5 years

Interviews were continued until a theoretical saturation was reached (46 experts were interviewed). For Delphi procedure, ten experts with better status were selected.

The questionnaires were based on a pairwise comparison of all elements, hence its validity. Moreover, they were submitted to nine experts (chosen out of the interviewees) for content validity evaluation and modified according to their comments. Furthermore, all model factors and criteria were compared pairwise and the highest possible number of questions were asked, thereby eliminating any need for reliability check. Research procedure algorithm was designed based on a scientific methodology as depicted in figure 1 .

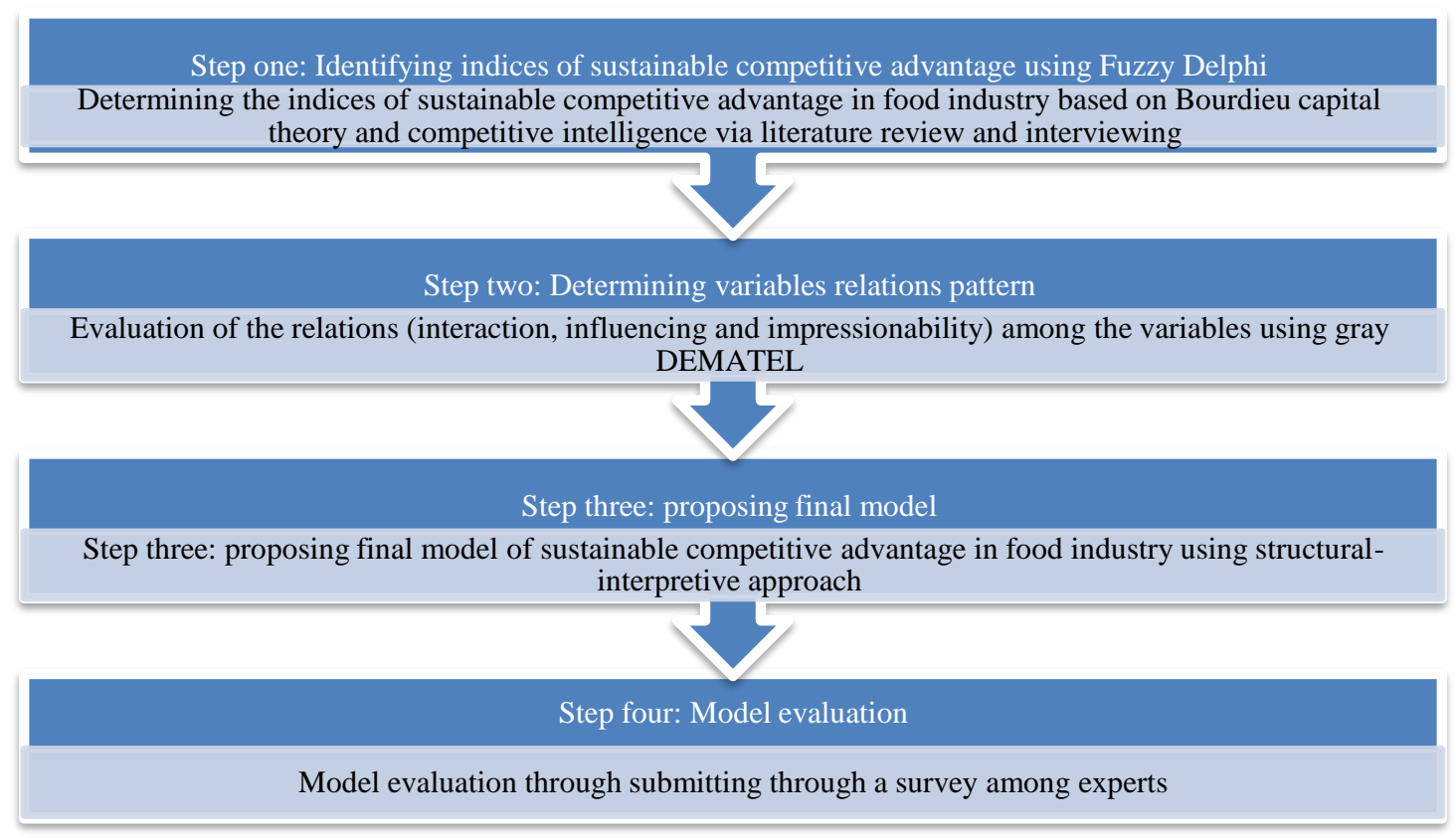

Figure1. Research execution algorithm 


\section{DATA ANALYSIS}

\section{Descriptive statistics}

Descriptive statistics was used to describe the collected data. Demographic properties of the respondents are presented in table 1. According to the table, most respondents (89\%) were married; $41 \%$ were 50-60 years old; 57\% had MA degree and 54\% had a work experience of 10 to 15 years.

Table 1. Demographic properties of the respondents

\begin{tabular}{|l|l|l|}
\hline \multirow{4}{*}{ Marriage status } & Married & 89 \\
\cline { 2 - 3 } Age & Single & 11 \\
\hline \multirow{5}{*}{ Education } & $30-40$ years & 19 \\
\cline { 2 - 3 } & $40-50$ & 28 \\
\cline { 2 - 3 } & $50-60$ & 41 \\
\cline { 2 - 3 } & $>60$ & 8 \\
\hline \multirow{5}{*}{ Work experience } & $\begin{array}{l}\text { Bachelor and } \\
\text { lower }\end{array}$ & 39 \\
\cline { 2 - 3 } & MA & 57 \\
\cline { 2 - 3 } & PhD & 4 \\
\hline & $5-10$ & 30 \\
\cline { 2 - 3 } & $10-15$ & 54 \\
\cline { 2 - 3 } & $>15$ & 34 \\
\hline
\end{tabular}

\section{Inferential statistics}

\section{Identifying the key factors affecting competitive advantage in food industry using fuzzy Delphi}

Identifying factors affecting competitive advantage is difficult and the background of competitive advantage is scarce in food industry; problem solving, accordingly, requires the cooperation of experts. In this regard, fuzzy Delphi was used to determine the key factors affecting competitive advantage and representing the core of this research. Fuzzy Delphi was performed as follows: At first, via literature review, 59 factors affecting competitive advantage were selected out of which, 36 factors were finally chosen based on the comments of nine experts in the context of Bourdieu capital theory and competitive intelligence together with two additional variables. Fuzzification was performed using Likert's five-point scale with identical distances. Fuzzy counterparts of the linguistic variables are presented in Table 2.

Table 2. Fuzzy numbers of linguistic variables (Bujadzief, 2002)

\begin{tabular}{|l|l|}
\hline Linguistic variables & Triangular fuzzy numbers \\
\hline Very high & $(0.75,1,1)$ \\
\hline High & $(0.5,0.75,1)$ \\
\hline Average & $(0.25,0.5,0.75)$ \\
\hline Low & $(0,0.25,0.5)$ \\
\hline Very low & $(0,0,0.25)$ \\
\hline
\end{tabular}


A questionnaire was then prepared and submitted to the experts based on the proposed items and linguistic variables represented in Table 3. In the second part of the survey, another questionnaire was prepared where the proposed items together with the previous comments of each expert and their differences (defuzzified means) were submitted to the expert panel. If the difference between experts' comments in two consecutive steps is lower than the very low threshold (0.1), the survey is stopped (Cheng and Lin, 2002). Finally, a consensus was achieved among the experts as to the components including EVA, national and international award, application of multiple brands, co-branding with famous firms, creating distinctive images, sustainable market share index, observed competitive advantage index, permanent use of global knowledge and organizational learning culture, keeping up with high standards, embedded credits and scientific quality, ethical issues, manufacturing machinery and excellent software and hardware, raw materials in supply chain, high startup capital, professional employees, international vision of managers, suitable pricing approach, appropriate strategies and policies, an accurate understanding of domestic and global technology, R\&D unit and permanent monitoring of market and customers' demands, entrepreneurial vision of top management, effective interaction with customers, cooperation with social and public organizations, timely alliance with competitors for market control, using network and WOM in advertising instead of media, internal trust and consistency between managers and staff, and creating trust among the customers with the differences lower than the very low threshold $(0.1)$ between the first and second steps; thus the survey was stopped with the significant difference being about 9 components.

In the third step of the survey, model criteria and components were modified and a third questionnaire was prepared and submitted to the experts. However, in this step, 27 out of 36 components were stopped and the survey was conducted on the remaining nine components. The disagreement among the experts as regards the nine items was lower than 0.1 , hence the survey was stopped. Compared with the previous steps, there existed, a suitable consensus among the expert in this step. Out of the various components, top managers' brand in food industry (with a score of -0.12) and cooperation with customers through branding process $(0.11)$ were removed from the model due to disagreement among experts. Therefore, after three steps, two criteria were removed and a model with 34 items was developed. Factors affecting competitive advantage were identified according to fuzzy Delphi method.

\section{Developing final model using ISM-Gray DEMATEL}

Gray multiple-criteria decision making models were used to determine the associations among the variables. For this purpose, gray DEMATEL technique was used where following the determination of the causal relations among the variables, interpretive-structural technique was applied to develop the final model.

\section{Calculating interrelations using GDEMATEL}

The main objective of this study was to elucidate competitive advantage based on Bourdieu capital theory and competitive intelligence using ISM-Gray DEMATEL. The main criteria included competitive intelligence, social capital, economic capital, symbolic capital, EVA, cultural capital, competitive advantage and MAV. The criteria were indexed with Ci to facilitate their tracking through the research. 
Table 3. Criteria of achieving competitive advantage in food industry and its symbols

\begin{tabular}{|l|l|l|l|l|l|l|l|l|}
\hline C8 & C7 & C6 & C5 & C4 & C3 & C2 & C1 \\
\hline $\begin{array}{l}\text { Market } \\
\text { value } \\
\text { added }\end{array}$ & $\begin{array}{l}\text { Competitive } \\
\text { advantage }\end{array}$ & $\begin{array}{l}\text { Cultural } \\
\text { capital }\end{array}$ & $\begin{array}{l}\text { Economic } \\
\text { value } \\
\text { added }\end{array}$ & $\begin{array}{l}\text { Symbolic } \\
\text { capital }\end{array}$ & $\begin{array}{l}\text { Social } \\
\text { capital }\end{array}$ & $\begin{array}{l}\text { Economic } \\
\text { capital }\end{array}$ & $\begin{array}{l}\text { Competitive } \\
\text { intelligence }\end{array}$ \\
\hline
\end{tabular}

Primarily, interrelations among the indices were identified, forming a matrix for the relationships among the main criteria. The interrelations of the main criteria were achieved by DEMATEL method, so the experts were enabled to express their ideas as to the severity and direction of the effects. It should be mentioned that DEMATEL matrix (interrelations matrix) is cause-effect, influencing the impressionability of the variables.

\section{Direct relation matrix}

In group DEMATEL technique, based on the ideas of certain experts, simple arithmetic mean was used and a direct relation matrix was formed. First, experts' ideas were individually grayed. The primary matrix of each expert was formed as follows:

$$
Z^{k}=\begin{gathered}
C_{1} \\
C_{2} \\
\vdots \\
C_{n}
\end{gathered}\left[\begin{array}{cccc}
{[0,0]} & \otimes z_{12}^{k} & \cdots & \otimes z_{1 n}^{k} \\
\otimes z_{21}^{k} & {[0,0]} & \cdots & \otimes z_{2 n}^{k} \\
\vdots & \vdots & \ddots & \vdots \\
\otimes z_{n 1}^{k} & \otimes z_{n 2}^{k} & \cdots & {[0,0]}
\end{array}\right]
$$

In this matrix, $Z_{i j}^{k}$ stands for the effect of the element $\mathrm{i}$ on element $\mathrm{j}$ based on kth expert vision. In order to form final direct relation matrix, the mean of experts' comments was calculated for each element:

$$
\mathrm{X}=\stackrel{2}{2}
$$

And a direct relation matrix $(\mathrm{X})$ was calculated by estimating the gray mean of experts' comments.

Table 4. Gray direct relation matrix

\begin{tabular}{|l|l|l|l|l|l|l|l|l|}
\hline $\mathrm{X}$ & $\mathrm{C} 1$ & $\mathrm{C} 2$ & $\mathrm{C} 3$ & $\mathrm{C} 4$ & $\mathrm{C} 5$ & $\mathrm{C} 6$ & $\mathrm{C} 7$ & $\mathrm{C} 8$ \\
\hline C1 & {$[0,0.3]$} & {$[0.32, .62]$} & {$[0.4,0.66]$} & {$[0.55,0.4]$} & {$[0.67, .16]$} & {$[0.42,0.78]$} & {$[0.47, .72]$} & {$[0.44,0.3]$} \\
\hline C2 & {$[0.45,0.6]$} & {$[0,0.3]$} & {$[0.55,0.4]$} & {$[0.51,0.36]$} & {$[0.41,0.56]$} & {$[0.34,0.62]$} & {$[0.43,0.68]$} & {$[0.53, .48]$} \\
\hline C3 & {$[0.38,0.66]$} & {$[0.31,0.48]$} & {$[0,0.3]$} & {$[0.47,0.32]$} & {$[0.41,0.72]$} & {$[0.36,0.66]$} & {$[0.31,0.6]$} & {$[0.46,0.62]$} \\
\hline C4 & {$[0.23,0.48]$} & {$[0.2,0.5]$} & {$[0.45,0.68]$} & {$[0,0.3]$} & {$[0.43,0.28]$} & {$[0.48,0.62]$} & {$[0.43,0.64]$} & {$[0.38, .66]$} \\
\hline C5 & {$[0.22,0.42]$} & {$[0.19,0.4]$} & {$[0.35,0.64]$} & {$[0.34,0.5]$} & {$[0,0.3]$} & {$[0.41,0.76]$} & {$[0.27,0.52]$} & {$[0.44,0.66]$} \\
\hline C6 & {$[0.32,0.62]$} & {$[0.39,0.56]$} & {$[0.55,0.64]$} & {$[0.44,0.66]$} & {$[0.44,0.58]$} & {$[0,0.3]$} & {$[0.6,0.38]$} & {$[0.38,0.7]$} \\
\hline C7 & {$[0.3,0.42]$} & {$[0.31,0.44]$} & {$[0.31,0.48]$} & {$[0.31,0.56]$} & {$[0.35,0.64]$} & {$[0.36,0.54]$} & {$[0,0.3]$} & {$[0.2,0.5]$} \\
\hline C8 & {$[0.22,0.42]$} & {$[0.19,0.4]$} & {$[0.34,0.62]$} & {$[0.29,0.44]$} & {$[0.25,0.48]$} & {$[0.4,0.62]$} & {$[0.21,0.48]$} & {$[0,0.3]$} \\
\hline
\end{tabular}

Calculating the normal direct relation matrix

Direct relation matrix was normalized using the following formula:

$$
\otimes \mathrm{S}=[\underline{S}, \bar{S}]=\frac{1}{\max \Sigma_{j}^{n} \otimes}
$$




$$
\mathrm{N}_{i j}=\left[\underline{S} \times \underline{X}_{i j} \bar{S} \times \bar{X}\right.
$$

The sum of the upper and lower bounds of each row was individually calculated. The elements of the lower bound were divided by the largest sum of the lower bounds. Elements of the upper bound were divided by the largest sum of the upper bounds.

Therefore,

$$
\otimes S=\left[\frac{1}{4.4}, \frac{1}{3.3}\right]
$$

Normalized matrix $(\mathrm{N})$ of the main criteria was formed as follows:

Table 5. Normalized matrix of the main criteria $(N)$

\begin{tabular}{|l|l|l|l|l|l|l|l|l|}
\hline $\mathrm{N}$ & $\mathrm{C} 1$ & $\mathrm{C} 2$ & $\mathrm{C} 3$ & $\mathrm{C} 4$ & $\mathrm{C} 5$ & $\mathrm{C} 6$ & $\mathrm{C} 7$ & $\mathrm{C} 8$ \\
\hline $\mathrm{C} 1$ & {$[0,0.092]$} & {$[0.072,0.19]$} & {$[0.09,0.202]$} & {$[0.124,0.122]$} & {$[0.151,0.049]$} & {$[0.095,0.239]$} & {$[0.106,0.22]$} & {$[0.099,0.092]$} \\
\hline $\mathrm{C} 2$ & {$[0.101,0.183]$} & {$[0,0.092]$} & {$[0.124,0.122]$} & {$[0.115,0.11]$} & {$[0.092,0.171]$} & {$[0.077,0.19]$} & {$[0.097,0.208]$} & {$[0.119,0.147]$} \\
\hline $\mathrm{C} 3$ & {$[0.086,0.202]$} & {$[0.07,0.147]$} & {$[0,0.092]$} & {$[0.106,0.098]$} & {$[0.092,0.22]$} & {$[0.081,0.202]$} & {$[0.07,0.183]$} & {$[0.104,0.19]$} \\
\hline $\mathrm{C} 4$ & {$[0.052,0.147]$} & {$[0.045,0.153]$} & {$[0.101,0.208]$} & {$[0,0.092]$} & {$[0.097,0.086]$} & {$[0.108,0.19]$} & {$[0.097,0.196]$} & {$[0.086,0.202]$} \\
\hline $\mathrm{C} 5$ & {$[0.05,0.128]$} & {$[0.043,0.122]$} & {$[0.079,0.196]$} & {$[0.077,0.153]$} & {$[0,0.092]$} & {$[0.092,0.232]$} & {$[0.061,0.159]$} & {$[0.099,0.202]$} \\
\hline $\mathrm{C} 6$ & {$[0.072,0.19]$} & {$[0.088,0.171]$} & {$[0.124,0.196]$} & {$[0.099,0.202]$} & {$[0.099,0.177]$} & {$[0,0.092]$} & {$[0.135,0.116]$} & {$[0.086,0.214]$} \\
\hline $\mathrm{C} 7$ & {$[0.068,0.128]$} & {$[0.07,0.135]$} & {$[0.07,0.147]$} & {$[0.07,0.171]$} & {$[0.079,0.196]$} & {$[0.081,0.165]$} & {$[0,0.092]$} & {$[0.045,0.153]$} \\
\hline $\mathrm{C} 8$ & {$[0.05,0.128]$} & {$[0.043,0.122]$} & {$[0.077,0.19]$} & {$[0.065,0.135]$} & {$[0.056,0.147]$} & {$[0.09,0.19]$} & {$[0.047,0.147]$} & {$[0,0.092]$} \\
\hline
\end{tabular}

Calculating the full relation matrix

For this purpose, the identity matrix (I) was formed and then deducted from the normalized matrix; the resulting matrix was inversed and, ultimately, the normalized matrix was multiplied by the inversed identity matrix:

$$
T=N \times(I-N)^{-1}
$$

\begin{tabular}{|c|c|c|c|c|c|c|c|c|}
\hline 1 & $\mathrm{C} 1$ & $\mathrm{C} 2$ & $\mathrm{C} 3$ & C4 & C5 & C6 & C7 & C8 \\
\hline $\mathrm{C} 1$ & {$[0.108,0.621]$} & {$[0.166,0.492]$} & {$[0.232,0.612]$} & {$[0.257,0.257]$} & {$[0.283,0.629]$} & {$[0.23,0.559]$} & {$[0.234,0.562]$} & {$[0.234,0.676]$} \\
\hline $\mathrm{C} 2$ & {$[0.201,0.549]$} & {$[0.099,0.59]$} & {$[0.259,0.682]$} & {$[0.25,0.25]$} & {$[0.233,0.532]$} & {$[0.214,0.545]$} & {$[0.225,0.579]$} & {$[0.251,0.633]$} \\
\hline C3 & {$[0.17,0.595]$} & {$[0.149,0.597]$} & {$[0.126,0.78]$} & {$[0.22,0.22]$} & {$[0.211,0.548]$} & {$[0.196,0.614]$} & {$[0.182,0.668]$} & {$[0.216,0.66]$} \\
\hline C4 & {$[0.138,0.605]$} & {$[0.125,0.559]$} & {$[0.213,0.638]$} & {$[0.118,0.118]$} & {$[0.208,0.63]$} & {$[0.214,0.594]$} & {$[0.201,0.619]$} & {$[0.194,0.612]$} \\
\hline C5 & {$[0.123,0.634]$} & {$[0.111,0.598]$} & {$[0.178,0.659]$} & {$[0.173,0.173]$} & {$[0.103,0.64]$} & {$[0.185,0.544]$} & {$[0.154,0.669]$} & {$[0.191,0.619]$} \\
\hline C6 & {$[0.173,0.617]$} & {$[0.178,0.588]$} & {$[0.255,0.699]$} & {$[0.231,0.231]$} & {$[0.233,0.604]$} & {$[0.137,0.539]$} & {$[0.254,0.737]$} & {$[0.216,0.652]$} \\
\hline C7 & {$[0.139,0.581]$} & {$[0.135,0.535]$} & {$[0.169,0.639]$} & {$[0.167,0.167]$} & {$[0.177,0.494]$} & {$[0.174,0.477]$} & {$[0.097,0.668]$} & {$[0.144,0.603]$} \\
\hline $\mathrm{C} 8$ & {$[0.115,0.559]$} & {$[0.104,0.527]$} & {$[0.164,0.583]$} & {$[0.152,0.152]$} & {$[0.145,0.516]$} & {$[0.171,0.494]$} & {$[0.132,0.597]$} & {$[0.089,0.642]$} \\
\hline
\end{tabular}

Table 6. Total relation matrix $(T)$ of the main criteria using gray values

Plotting the network relation map

Estimating the threshold value specifies the network relation map (NRM). This method enables us to ignore negligible relations and plot the significant ones. NRM shows the relations whose values are higher than threshold value in matrix T. For this purpose, gray values were converted to white values. Full relation matrix is presented in the following table: 
Table 7. Total relation matrix $(T)$ of the main criteria using crisp values

\begin{tabular}{|l|l|l|l|l|l|l|l|l|}
\hline Tw & C8 & C7 & C6 & C5 & C4 & C3 & C2 & C1 \\
\hline C1 & 0.455 & 0.398 & 0.395 & 0.456 & 0.257 & 0.422 & 0.329 & 0.364 \\
\hline C2 & 0.442 & 0.402 & 0.379 & 0.382 & 0.424 & 0.471 & 0.344 & 0.375 \\
\hline C3 & 0.438 & 0.425 & 0.405 & 0.379 & 0.362 & 0.453 & 0.373 & 0.383 \\
\hline C4 & 0.403 & 0.410 & 0.404 & 0.419 & 0.386 & 0.426 & 0.342 & 0.372 \\
\hline C5 & 0.405 & 0.411 & 0.364 & 0.371 & 0.388 & 0.418 & 0.355 & 0.379 \\
\hline C6 & 0.434 & 0.495 & 0.338 & 0.419 & 0.421 & 0.477 & 0.383 & 0.395 \\
\hline C7 & 0.373 & 0.382 & 0.325 & 0.336 & 0.352 & 0.404 & 0.335 & 0.360 \\
\hline C8 & 0.365 & 0.364 & 0.332 & 0.331 & 0.346 & 0.373 & 0.315 & 0.337 \\
\hline
\end{tabular}

The mean of matrix $\mathrm{T}$ is calculated to estimate the threshold values of the relations. Once threshold values are determined, all values of matrix $\mathrm{T}$ lower than threshold are regarded as zero, meaning that the causal relation is ignored. In this study, threshold value was estimated 0.387. Since this matrix is used as the input matrix in ISM, significant relations are assigned 1 and those with values lower than threshold are assigned zero. The pattern of significant relations is presented in the below table.

Table 8. Pattern of significant relations of the main criteria

\begin{tabular}{|l|l|l|l|l|l|l|l|l|}
\hline Tm & C8 & C7 & C6 & C5 & C4 & C3 & C2 & C1 \\
\hline C1 & 1 & 1 & 1 & 1 & 0 & 1 & 0 & 0 \\
\hline C2 & 1 & 1 & 0 & 0 & 1 & 1 & 0 & 0 \\
\hline C3 & 1 & 1 & 1 & 0 & 0 & 1 & 0 & 0 \\
\hline C4 & 1 & 1 & 1 & 1 & 0 & 1 & 0 & 0 \\
\hline C5 & 1 & 1 & 0 & 0 & 1 & 1 & 0 & 0 \\
\hline C6 & 1 & 1 & 0 & 1 & 1 & 1 & 0 & 1 \\
\hline C7 & 0 & 0 & 0 & 0 & 0 & 1 & 0 & 0 \\
\hline C8 & 0 & 0 & 0 & 0 & 0 & 0 & 0 & 0 \\
\hline
\end{tabular}

\section{Interpretive structural modeling}

Interpretive structural modeling was first proposed by Sidge in 1977. In this study, after identifying the criteria and indices, the relation between the indicators and dimensions resulted in analysis using the conceptual relation. Next, the interrelations of the main criteria were determined to obtain the super matrix of causal relations pattern using experts' comments, enabling experts to express their ideas about the severity and direction of the effects. The resulting matrix (interrelations matrix) shows the cause-effect, influence and impressionability of the variables.

\section{Formation of structural self-interaction matrix}

Structural self-interaction matrix is formed by criteria and indices and their comparison through four statuses of the conceptual relations. The resulting information was summarized based on ISM and the final structural self-interaction matrix was formed (Azar and Bayat, 2008). Reachability matrix is formed by converting the self-interaction matrix to a 0 and 1 twovalue matrix. In this matrix, elements of the main diameter are assigned 1 . Secondary relations have to be controlled, meaning that if $\mathrm{A}$ results in $\mathrm{B}$ and $\mathrm{B}$ results in $\mathrm{C}$, then $\mathrm{A}$ must result in $\mathrm{C}$, otherwise the table12 is to be adjusted such that it shows the secondary relations. The reachability matrix of ISM technique is presented in the last table. 
Determining the relations and levels of criteria and indices

So as to determine the relations and levels of criteria and indices, we extracted the sum of inputs and outputs for each criterion. The total outputs set includes the criterion and those influenced by the criterion, while the total inputs set includes the criterion and those affecting it. A two-tailed relations pattern of the criteria was then determined.

Table 9. Sum of inputs and outputs for the determination of the level

\begin{tabular}{|l|l|l|}
\hline & Input, impressionability & Output, influence \\
\hline Competitive intelligence & C1,C6 & C1,C3,C5,C6,C7,C8 \\
\hline Economic capital & C2,C4 & C2,C3,C4,C6,C7,C8 \\
\hline Social capital & C1,C2,C3,C7,C8 & C3,C7,C8 \\
\hline Symbolic capital & C2,C4,C5,C6,C7 & C2,C4,C5,C8 \\
\hline EVA & C1,C4,C5,C6,C7 & C4,C5 \\
\hline Cultural capital & C1,C2,C6 & C1,C4,C5,C6,C7,C8 \\
\hline Competitive advantage & C1,C2,C3,C6,C7 & C3,C4,C5,C7,C8 \\
\hline MVA & C1,C2,C3,C4,C6,C7,C8 & C3,C8 \\
\hline
\end{tabular}

The first row which is the intersection of the two sets is equal to achievable (inputs) set, indicating the first level of priority. If intersection of the inputs set and outputs set is equal, the corresponding variable is placed in the highest position of ISM hierarchy. After determining the level, the criterion whose level is determined is removed from the set and a new set of inputs and outputs is formed where the level of the next variable is obtained.

Table10. Determining the first level in ISM hierarchy

\begin{tabular}{|l|l|l|l|l|}
\hline & Output, influence & $\begin{array}{l}\text { Input, } \\
\text { impressionability }\end{array}$ & Shared & level \\
\hline Competitive intelligence & C1,C3,C5,C6,C7,C8 & C1,C6 & C1,C6 & 1 \\
\hline Economic capital & C2,C3,C4,C6,C7,C8 & C2,C4 & C2,C4 & 1 \\
\hline Social capital & C3,C7,C8 & C1,C2,C3,C7,C8 & C3,C7,C8 & \\
\hline Symbolic capital & C2,C4,C5,C8 & C2,C4,C5,C6,C7 & C2,C4,C5 & \\
\hline EVA & C4,C5 & C1,C4,C5,C6,C7 & C4,C5 & \\
\hline Cultural capital & C1,C4,C5,C6,C7,C8 & C1,C2,C6 & C1,C6 & \\
\hline Competitive advantage & C3,C4,C5,C7,C8 & C1,C2,C3,C6,C7 & C3,C7 & \\
\hline MVA & C3,C8 & $\begin{array}{l}\text { C1,C2,C3,C4,C6 } \\
\text {,C7,C8 }\end{array}$ & C3,C8 & \\
\hline
\end{tabular}

Therefore, competitive intelligence and economic capital are the variables of the first level which were then removed and a new set of inputs and outputs was formed without considering the variables of the first level. Once the Intersection set is determined, variables whose intersection is equal to inputs set are considered as the variable of the second level. Table 15 presents the calculation process of determining the second level in Ism hierarchy.

Table11. Determining the second level in ISM hierarchy

\begin{tabular}{|l|l|l|l|l|}
\hline & Output, influence & Input, impressionability & Shared & level \\
\hline Social capital & C3,C7,C8 & C3,C7,C8 & C3,C7,C8 & 2 \\
\hline Symbolic capital & C4,C5,C8 & C4,C5,C6,C7 & C4,C5 & \\
\hline EVA & C4,C5 & C4,C5,C6,C7 & C4,C5 & \\
\hline Cultural capital & C4,C5,C6,C7,C8 & C6 & C6 & 2 \\
\hline Competitive advantage & C3,C4,C5,C7,C8 & C3,C6,C7 & C3,C7 & \\
\hline MVA & C3,C8 & C3,C4,C6,C7,C8 & C3,C8 & \\
\hline
\end{tabular}


According to the results, social capital and cultural capital are the variables of the second level. To determine the elements of the third level, those placed in the second level are removed and a new set of inputs and outputs is formed without considering the variables of the second level. The intersection set is determined and the variables whose intersection is equal to inputs set are considered as the variables of the third level.

Table12. Determining the elements of the third level

\begin{tabular}{|l|l|l|l|l|}
\hline & Output, influence & Input, impressionability & Shared & level \\
\hline Symbolic capital & C4,C5,C8 & C4,C5,C7 & C4,C5 & \\
\hline EVA & C4,C5 & C4,C5,C7 & C4,C5 & \\
\hline Competitive advantage & C4,C5,C7,C8 & C7 & C7 & 3 \\
\hline MVA & C8 & C4,C7,C8 & C8 & \\
\hline
\end{tabular}

According to the calculations, competitive advantage is determined as the variable of the third level.

Table13. Determining the elements of the fourth level

\begin{tabular}{|l|l|l|l|l|}
\hline & Output, influence & Input, impressionability & Shared & level \\
\hline Symbolic capital & C4,C5,C8 & C4,C5 & C4,C5 & 4 \\
\hline EVA & C4,C5 & C4,C5 & C4,C5 & 4 \\
\hline MVA & C8 & C4,C8 & C8 & \\
\hline
\end{tabular}

Symbolic capital and EVA were selected as the variables placed at the fourth level. Finally, MVA was determined as the variable of the last level. The final pattern of the variables' levels is presented in Figure 4 which illustrates the significant relation of the variables of each level with those positioned in the lower level along with the significant interdependencies of each row's elements.

Adding the variables' names, we reach:

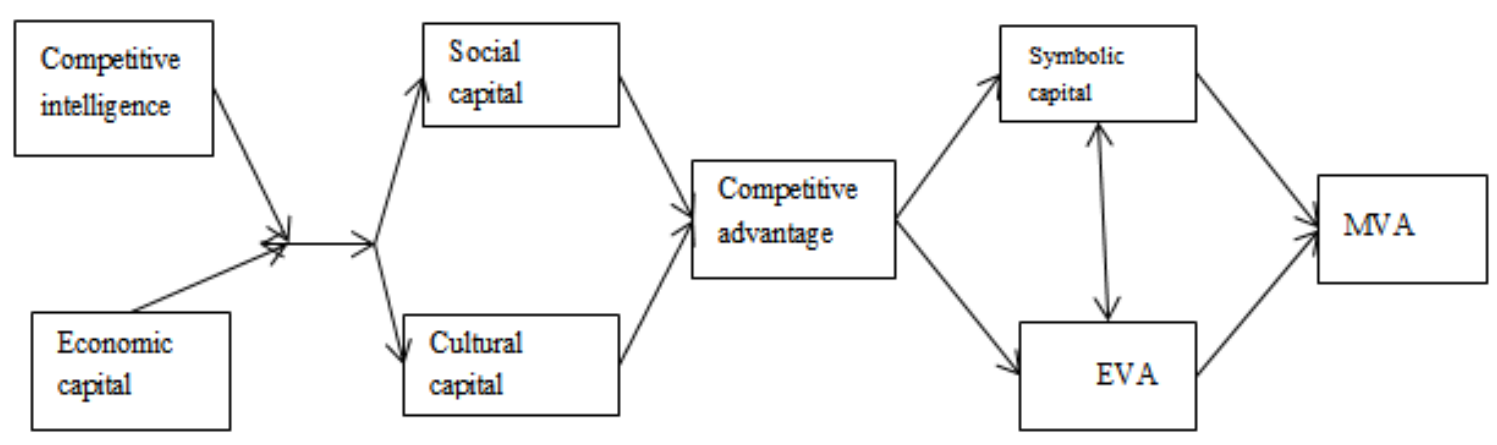

Figure 2. Basic model developed by adding variables' names 


\section{CONCLUSION}

The main objective of this study was to explain and develop a hybrid model of competitive advantage based on Bourdieu capital theory and competitive intelligence using fuzzy Delphi and ISM-Gray DEMATEL in Iran food industry. Based on the results, certain recommendations are proposed to managers and decision makers of the food industry.

Based on Delphi results, managers and decision makers of food industry should pay a great deal of attention to EVA, national and international award, application of multiple brands, cobranding with famous firms, creating distinctive image, sustainable market share index, observed competitive advantage index, permanent use of global knowledge and organizational learning culture, keeping up with high standards, embedded credits and scientific quality, ethical issues, manufacturing machinery and excellent software and hardware, raw materials in the supply chain, high startup capital, professional employees, international visions, suitable pricing approach, appropriate strategies and policies, a thorough understanding of domestic and global technology, R\&D unit and permanent monitoring of market and customers' demands, entrepreneurial vision of top management, effective interaction with customers, cooperation with social and public organizations, timely alliance with competitors for market control, using network and WOM for advertising instead of media, internal trust and consistency between managers and staff, and establishing trust among the customers for planning.

Based on the results of modeling tests and evaluation via ISM-DEMATEL, it is recommended that administrators promote competitive intelligence, and truly understand $\mathrm{i}$ business and startup capital to achieve competitive advantage. In doing so, an organization can make better use of social and cultural capital. Optimal use of social and cultural capital improves the competitive advantage of these organizations in the market, enhancing their credit, EVA and MVA

Based on experts' emphasis on certain indices, it can be concluded that the following can positively affect profitability via increasing customers' satisfaction and promoting sale: Increasing investment in advertising rate and $R \& D$ system, reducing price and strengthening the customer relation management and customer experience management, and paying a lot of heed to such communication tools as personal interaction and relationships with foreign distributers. Increasing customer satisfaction influences their loyalty to the brand and its power and reputation (symbolic capital), thereby promoting market share (competitive advantage). Possessing a market-oriented export approach is an indispensable part of superior export performance. Accordingly, it is indispensable to increase export marketing skills in firms seeking regular export, through allocating sufficient resources to export marketing R\&D. Notwithstanding the rather high cost of $R \& D$, such practices reduce the uncertainty of export marketing decisions. 


\section{REFRENCES}

[1] Ali Köseoglu, M., Ross, G., \& Okumus, F. (2016). Competitive intelligence practices in hotels. International Journal of Hospitality Management, 53, 161-172. doi:10.1016/j.ijhm.2015.11.002

[2] Antelo, M., Magdalena, P., \& Reboredo, J. C. (2017). Economic crisis and the unemployment effect on household food expenditure: The case of Spain. Food Policy, 69, 11-24. doi:http://dx.doi.org/10.1016/j.foodpol.2017.03.003

[3] Ayse, Valentine; Nash, Jason John; Leland, Rice (January 2013). "The Business Year 2013: Iran". London, U.K.: The Business Year: 138. ISBN 978-1-908180-11-7.

[4] Barthélemy, J. (2017), The impact of technical consultants on the quality of their clients' products: Evidence from the Bordeaux wine industry. Strat. Mgmt. J., 38: 1174-1190. doi:10.1002/smj.2531

[5] Baxter, J., \& Chua, W. F. (2008). Be(com)ing the chief financial officer of an organisation: Experimenting with Bourdieu's practice theory. Management Accounting Research, 19(3), 212-230. doi:10.1016/j.mar.2008.06.001

[6] Borseková, K., Vaňová, A., \& Vitálišová, K. (2016). Smart Specialization for Smart Spatial Development: Innovative Strategies for Building Competitive Advantages in Tourism in Slovakia. Socio-Economic Planning Sciences. doi:10.1016/j.seps.2016.10.004

[7] Chavas, J.-P. (2017). On food security and the economic valuation of food. Food Policy, 69, 58-67. doi:http://dx.doi.org/10.1016/j.foodpol.2017.03.008

[8] Cooper, C., \& Coulson, A. B. (2014). Accounting activism and Bourdieu's 'collective intellectual' - Reflections on the ICL Case. Critical Perspectives on Accounting, 25(3), 237-254. doi:10.1016/j.cpa.2013.01.002

[9] Davcik, N. S., \& Sharma, P. (201 .(6Marketing resources, performance, and competitive advantage: A review and future research directions. Journal of Business Research, 69(12), 5547-5552. doi:10.1016/j.jbusres.2016.04.169

[10] Harris, L. C., \& Ogbonna, E. (2001). Competitive advantage in the UK food retailing sector: past, present and future. Journal of Retailing and Consumer Services, 8(3), 157173. doi:http://dx.doi.org/10.1016/S0969-6989(00)00009-6

[11] Hsu, P.-F. (2013). Commodity or competitive advantage? Analysis of the ERP value paradox. Electronic Commerce Research and Applications, 12(6), 412-424. doi:10.1016/j.elerap.2013.06.004

[12] Ihlen, Ø. (2005). The power of social capital: Adapting Bourdieu to the study of public relations. Public Relations Review, 31(4), 492-496. doi:10.1016/j.pubrev2005.08.007.

[13] Ihlen, Ø. (2007). Building on Bourdieu: A sociological grasp of public relations. Public Relations Review, 33(3), 269-274. doi:10.1016/j.pubrev.2007.05.005

[14] "Iran's foodstuff exports near \$1b". tehran times. Retrieved 2012-02-07

[15] Jensen, J. A., Cobbs, J. B., \& Turner, B. A. (2016). Evaluating sponsorship through the lens of the resource-based view: The potential for sustained competitive advantage. Business Horizons, 59(2), 163-173. doi:10.1016/j.bushor.2015.11.001

[16] Kitchin, P. J., \& David Howe, P. (2013). How can the social theory of Pierre Bourdieu assist sport management research? Sport Management Review, 16(2), 123-134. doi:10.1016/j.smr.2012.09.003

[17] Klimek, B., \& Hansen, H. O. (2017). Food industry structure in Norway and Denmark since the 1990s: Path dependency and institutional trajectories in Nordic food markets. Food Policy, 69, 110-122. doi:http://dx.doi.org/10.1016/j.foodpol.2017.03.009

[18] Kress-Rogers, E.; Brimelow, C.J.B. (2001). Instrumentation and Sensors for the Food Industry. Woodhead Publishing Series in Food Science, Technology and Nutrition. Woodhead. ISBN 978-1-85573-560-6. 836 pages. 
[19]Lieberman, M. B., Garcia-Castro, R. and Balasubramanian, N. (2017), Measuring value creation and appropriation in firms: The VCA model. Strat. Mgmt. J., 38: 1193-1211. doi: $10.1002 / \mathrm{smj} .2565$

[20] Mariadoss, B. J., Milewicz, C., Lee, S., \& Sahaym, A. (2014). Salesperson competitive intelligence and performance: The role of product knowledge and sales force automation usage. Industrial Marketing Management, 43(1), 136-145. doi:10.1016/j.indmarman.2013.08.005

[21] Massa, S., \& Testa, S. (2009). A knowledge management approach to organizational competitive advantage: Evidence from the food sector. European Management Journal, .141-129, (2)27doi:10.1016/j.emj.2008.06.005

[22] Menrad, K. (2004) Innovation in the food industry in Germany. Research Policy 33(6-7), 845-878.

[23]Nestle, M. (2013). Food Politics: How the Food Industry Influences Nutrition and Health. California Studies in Food and Culture. University of California Press. ISBN 978-0-52095506-6. 534 pages.

[24]Perez, M. P., Ribera, L. A., \& Palma, M. A. (2017). Effects of trade and agricultural policies on the structure of the U.S. tomato industry. Food Policy, 69, 123-134. doi:http://dx.doi.org/10.1016/j.foodpol.2017.03.011

[25] Perren, L. (2013). Strategic discourses of 'competitive advantage': Comparing social representation of causation in academia and practice. Scandinavian Journal of Management, 29(3), 235-246. doi:10.1016/j.scaman.2012.12.001

[26]Peters, M. D., Wieder, B., Sutton, S. G., \& Wakefield, J. (2016). Business intelligence systems use in performance measurement capabilities: Implications for enhanced competitive advantage. International Journal of Accounting Information Systems, 21, 117. doi:10.1016/j.accinf.2016.03.001

[27]Rui, H., Zhang, M., \& Shipman, A. (2017). Chinese expatriate management in emerging markets: A competitive advantage perspective. Journal of International Management. doi:10.1016/j.intman.2017.01.002

[28] Sewdass, N., \& Toit, A. D. (2014). Current state of competitive intelligence in South Africa. International Journal of Information Management, 34(2), 185-190. doi:10.1016/j.ijinfomgt.2013.10.006

[29] Shi, W., Connelly, B. L. and Hoskisson, R. E. (2017), External corporate governance and financial fraud: cognitive evaluation theory insights on agency theory prescriptions. Strat. Mgmt. J., 38: 1268-1286. doi:10.1002/smj.2560

[30] Shih, M.-J., Liu, D.-R., \& Hsu, M.-L. (2010). Discovering competitive intelligence by mining changes in patent trends. Expert Systems with Applications, 37(4), 2882-2890. doi:10.1016/j.eswa.2009.09.001

[31] Sieweke, J. (2014). Pierre Bourdieu in management and organization studies-A citation context analysis and discussion of contributions. Scandinavian Journal of Management, 30(4), 532-543. doi:10.1016/j.scaman.2014.04.004

[32] Teixeira, E. d. O., \& Werther, W. B. (2013). Resilience: Continuous renewal of competitive advantages. Business Horizons, 56(3), 333-342. doi:10.1016/j.bushor.2013.01.009

[33] Topliceanu, L ,.Bibire, L., \& Nistor, D. (2015). Professional Competences of the Personnel Working on Quality Control and Food Safety in the Food Industry. Procedia Social and Behavioral Sciences, 180, 1030-1037. doi:http://dx.doi.org/10.1016/j.sbspro.2015.02.198

[34] Traill, B.; Pitts, E. (1998). Competitiveness in the Food Industry. Springer. ISBN 978-07514-0431-9. 301 pages. 
[35] Vasconcellos, J.A. (2003). Quality Assurance for the Food Industry: A Practical Approach. CRC Press. ISBN 978-0-203-49810-1. 448 pages.

[36] Wongprawmas, R., \& Canavari, M. (2017). Consumers' willingness-to-pay for food safety labels in an emerging market: The case of fresh produce in Thailand. Food Policy, 69, 25-34. doi:http://dx.doi.org/10.1016/j.foodpol.2017.03.004

\section{Article history:}

Received 23 April 2019

Accepted 18 June 2019 